Article

\title{
Synthesis, Modeling Study and Antioxidants Activity of New Heterocycles Derived from 4-Antipyrinyl-2-Chloroacetamidothiazoles
}

\author{
Sraa Abu-Melha \\ Department of Chemistry, Faculty of Science of Girls, King Khaled University, Abha 62529, Saudi Arabia; \\ sabomlha@kku.edu.sa; Tel.: +966-504-757-797
}

Received: 15 October 2018; Accepted: 30 October 2018; Published: 1 November 2018

\begin{abstract}
The present work reports the preparation of twelve new heterocyclic scaffolds containing an antipyrinyl-thiazole hybrid through the reaction of 4-antipyrinyl-2-chloroacetamido-thiazoles 1 and 6 with various types of nucleophiles, namely; ethyl thioglycolate, 2-mercaptobenzothiazole, 2-mercaptobenzoxazole, ammonium thiocyanate, malononitrile, and salicylaldehyde. The constructed compounds were characterized by conventional spectroscopic techniques (IR, ${ }^{1} \mathrm{H} N \mathrm{NR},{ }^{13} \mathrm{C} \mathrm{NMR}$, and mass analysis). A DFT method (material studio package) was used to predict the geometry, bond lengths, bond angles, and dipole moments as well as other global chemical reactivities of the constructed antipyrinyl-thiazole compounds. Also, their semi-core pseudopods calculations (dspp) were carried out with DNP (double numerical basis sets plus polarization functional) to predict the properties of materials. In addition, the antioxidant activity of these antipyrinyl-thiazole scaffolds has been screened by the ABTS method. The results indicated that 2-(4-antipyrinylthiazolylamino)-5-substituitedbenzylidene-thiazol-4(5H)-ones $\mathbf{1 0 b}$ and 10c exhibited the best antioxidant activity with a percentage inhibition of $85.74 \%$ and $83.51 \%$, respectively.
\end{abstract}

Keywords: 2-amino-4-antipyrinylthiazole; chloroacetyl chloride; 2-chloroacetamido-4-antipyrinylthiazole; salicylaldehyde; ammonium thiocyanate; $N$-(thiazol-2-yl)-benzofuran-2-carboxamide; ABTS

\section{Introduction}

The antipyrine nucleus has been utilized as a useful precursor for the construction of many biologically important heterocycles [1,2]. Antipyrine derivatives are of great interest in medicine as a result of their broad range of pharmacological activity and clinical applications, including antibacterial [3], analgesic [4], and anti-inflammatory [4,5] as well as antitumor activity [6,7]. Antipyrine scaffolds are strong inhibitors of cyclooxygenase isoenzymes and platelet thromboxane and prostanoids synthesis [8,9]. In addition, thiazoles are valuable basic units in the field of medicinal science and are found in a wide assortment of bioactive scaffolds $[10,11]$. It has been well established that they possess antibacterial [12,13], anti-inflammatory [14,15], antitubercular [16,17], anticonvulsant [18,19], and anticancer [20-23] activities. Aminothiazole-containing medicines have been applied in clinical use for over thirty years, e.g., Famotidine is used to treat and prevent gastroesophageal reflux disease [24,25], Abafungin as an antifungal agent is used in the treatment of dermatomycoses [26] and Cefdinir is a well-known FDA-approved antibiotic and a third generation broad-spectrum cephalosporin [27]. Recently, some new thiazoles have been synthesized and proved to possess antioxidant power and DNA damage inhibition ability $[28,29]$. In light of these previous reports, we envisaged that integrating antipyrine and thiazole nuclei in one molecule could potentially produce new molecular hybrids with significant synergistic antioxidant activities. 


\section{Results and Discussion}

\subsection{Synthesis}

The focus of this research paper, 4-antipyrinyl-2-chloroacetamidothiazole (1), has been obtained by stirring 2-amino-4-antipyrinylthiazole with chloroacetyl chloride in DMF and triethylamine for $4 \mathrm{~h}$ [30]. Heating of chloroacetamide derivative $\mathbf{1}$ with ethyl thioglycolate in absolute ethyl alcohol and sodium acetate furnished one product (TLC), which was identified as ethyl 2-[(2-((4-antipyrinylthiazol-2-yl)amino)-2-oxoethyl)thio]acetate (2) based on its spectral and elemental analyses, see Scheme 1.

Chloroacetamide derivative 1 reacted with 3-cyano-4,6-dimethyl-2-mercaptopyridine (3) in acetone and sodium carbonate to afford $N$-(4-antipyrinylthiazol-2-yl)-2-((3-cyano-4,6dimethylpyridin-2-yl)thio)-acetamide (4), which underwent intramolecular cyclization in hot ethanolic sodium ethoxide solution furnishing the conforming 3-aminothieno[2,3-b]pyridine derivative 5, as shown in Scheme 1. The formation of 5 may be interpreted through the nucleophilic attack of active methylene on the cyano group according to the mechanistic consideration. Structural proof of 4 and 5 was verified from their compatible spectral analyses including $I R,{ }^{1} \mathrm{H}$ NMR, and ${ }^{13} \mathrm{C} N M R$. The infrared spectrum of 4 revealed the absorption of nitrile function at $2219 \mathrm{~cm}^{-1}$ that disappeared from the infrared spectrum of compound 5, indicating the cyclization process had occurred. The ${ }^{1} \mathrm{H}$ NMR spectrum of 4 displayed the two protons of the methylene group as a singlet signal at 4.05 ppm, this signal was no longer present in the spectrum of the product 5, providing additional evidence for the successful cyclization reaction.

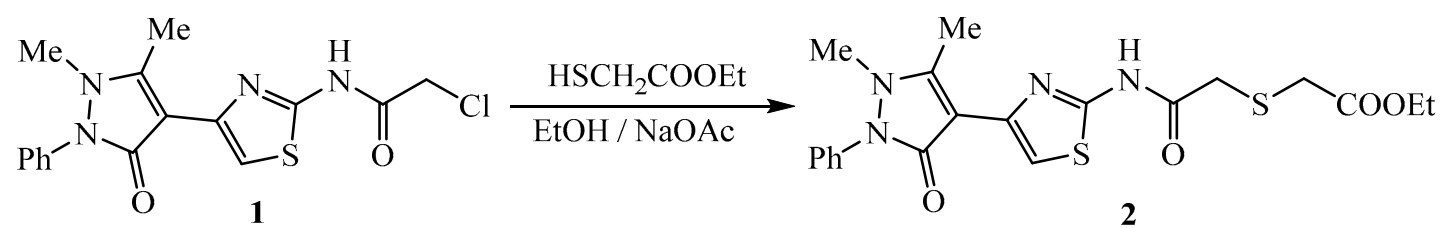<smiles>Cc1cc(C)c(C#N)c(S)n1</smiles><smiles></smiles>

Scheme 1. Reaction of thiazolyl-chloroacetamide 1 with ethyl thioglycolate and 3-cyano-4,6-dimethyl2-mercaptopyridine.

The reactivity of C-5 of thiazole ring in the key compound, 4-antipyrinyl-2chloroacetamidothiazole (1) towards electrophilic diazo-coupling reaction was investigated. Thus, the coupling reaction of compound $\mathbf{1}$ with diazotized sulphanilamide was carried out in ethanol containing sodium acetate at $0-5{ }^{\circ} \mathrm{C}$ to furnish 4-antipyrinyl-2-chloroacetamido5-(4-sulfamoylphenylazo)thiazole (6), see Scheme 2. The infrared spectrum of 6 showed three characteristic absorptions at 3351,3264, and $1697 \mathrm{~cm}^{-1}$ to indicate the presence of $-\mathrm{NH}_{2}, \mathrm{~N}-\mathrm{H}$, and $\mathrm{C}=\mathrm{O}$ functional groups, respectively. The ${ }^{1} \mathrm{H}$ NMR spectrum displayed four singlet signals at $\delta$ $2.72 \mathrm{ppm}$ for three protons of $\mathrm{CH}_{3}-\mathrm{C}$, at $\delta 3.28 \mathrm{ppm}$ for three protons of $\mathrm{CH}_{3}-\mathrm{N}$, at $\delta 4.44$ ppm for two protons of $-\mathrm{CH}_{2}$ - group, and at $\delta 12.92 \mathrm{ppm}$ for one proton of N-H. In addition, a multiplet signal 
for the aromatic protons and $\mathrm{NH}_{2}(\delta 7.28-7.61 \mathrm{ppm})$, and a doublet signal for the two protons at $\delta$ 7.94-8.00 ppm (AA'-BB' system of the 1,4-disubstituted phenyl ring).<smiles></smiles>

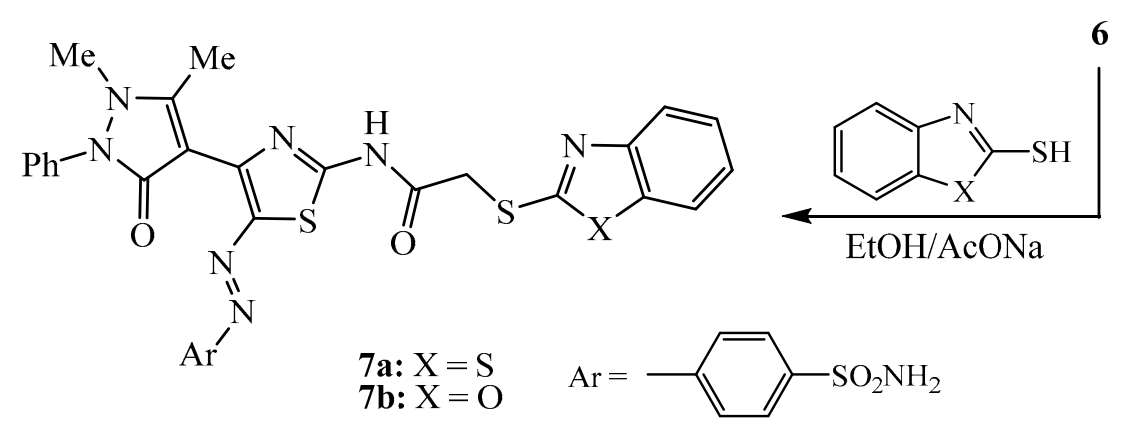

Scheme 2. Reaction of thiazolyl-chloroacetamide 6 with 2-mercaptobenzothiazole and/ or 2-mercaptobenzoxazole.

The reaction of 2-chloroacetamido-thiazole derivative 6 with 2-mercaptobenzothiazole and/or 2-mercaptobenzoxazole was achieved by refluxing in ethyl alcohol and sodium acetate for $2 \mathrm{~h}$ to furnish the corresponding sulfide derivatives $7 \mathbf{a}$ and $7 \mathbf{b}$, respectively. The chemical structures of $7 \mathbf{a}$ and $\mathbf{7 b}$ were deduced from their compatible spectral and elemental analyses.

Treatment of the key compound $\mathbf{1}$ with ammonium thiocyanate in refluxing ethanol has been described to furnish 2-((4-antipyrinylthiazol-2-yl)imino)thiazolidin-4-one (9). A plausible mechanism for the reaction is indicated in scheme 3. The reaction proceeds via intramolecular cyclization of the thiocyanate intermediate 8 and the Dimroth-like rearrangements [31]. The product of this reaction was designed as the lactam derivative $\mathbf{9}$ and finds support from the literature of Vicini et al. [32]. The constructed thiazolidin-4-one scaffold 9 underwent condensation with three para-substituted benzaldehyde derivatives in glacial $\mathrm{CH}_{3} \mathrm{COOH}$ and anhydrous $\mathrm{CH}_{3} \mathrm{COONa}$ (Knoevenagel condensation reaction) furnishing the corresponding 2-(4-antipyrinylthiazol-2ylamino)-5-(substituted-benzylidene)-thiazol-4(5H)-one derivatives 10a-c in good yields, see Scheme 3 . The chemical structures of $\mathbf{1 0 a - c}$ were determined based on their compatible spectral analyses. Thus, the IR spectrum of 10a showed the characteristic absorptions at 3176 and $1698 \mathrm{~cm}^{-1}$ referring to the functional groups $-\mathrm{NH}$ - and carbonyl $(\mathrm{C}=\mathrm{O})$, respectively. The ${ }^{1} \mathrm{H}$ NMR spectrum of the same scaffold exhibited a singlet for three protons at $\delta 2.61 \mathrm{ppm}\left(\mathrm{CH}_{3}-\mathrm{C}\right)$, a singlet for three protons at $\delta 2.28 \mathrm{ppm}$ $\left(\mathrm{CH}_{3}-\mathrm{N}\right)$, a singlet for three protons at $\delta 3.84 \mathrm{ppm}\left(\mathrm{OCH}_{3}\right)$, and a doublet for two protons at $\delta 7.14 \mathrm{ppm}$ (aromatic protons). The aromatic and thiazole C-5 protons resonated as a multiplet ( $\delta 7.28-7.62 \mathrm{ppm})$, the olefinic proton resonated as a singlet at $\delta 7.73 \mathrm{ppm}$, while the proton on $\mathrm{N}-\mathrm{H}$ function resonated as a singlet at $\delta 12.62 \mathrm{ppm}$. In compounds 10a-c, the $\mathrm{Z}$ conformation of the exocyclic $\mathrm{C}=\mathrm{C}$ double bond was assigned on the basis of ${ }^{1} \mathrm{H}$ NMR spectroscopy and on the basis of literature data for analogous 4-thiazolidinones [33]. The ${ }^{1} \mathrm{H}$ NMR spectra of compounds 10a-c showed only one kind of methine proton that, deshielded by the adjacent $\mathrm{C}=\mathrm{O}$, was detected at 7.73-7.78 ppm, which are higher chemical shift values than those expected for $\mathrm{E}$ isomers. 
<smiles>CCOC(=N)N[NH2+]C(=O)CC(=O)Nc1nc(-c2c(C)n(C)n(-c3ccccc3)c2=O)cs1</smiles>

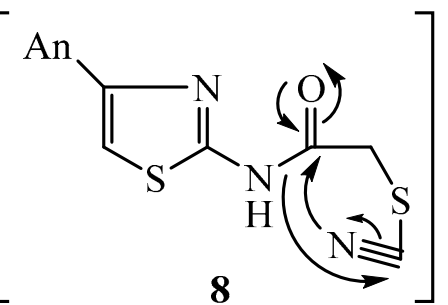<smiles></smiles><smiles>CC(C)C(=O)ONC(=O)O</smiles><smiles>O=C1CS/C(=N\c2nc([AlH2])cs2)N1</smiles>

10a: $\mathrm{Ar}=4-\mathrm{MeOC}_{6} \mathrm{H}_{4}$ 10b: $\mathrm{Ar}=4-\mathrm{NO}_{2} \mathrm{C}_{6} \mathrm{H}_{4}$ 10c: $\mathrm{Ar}=4-\mathrm{BrC}_{6} \mathrm{H}_{4}$<smiles>Cc1c(C)n(C)n(-c2ccccc2)c1=O</smiles>

9

Scheme 3. Preparation of 2-((4-antipyrinylthiazol-2-yl)imino)thiazolidin-4-one scaffolds 9 and 10a-c.

Condensation reaction of equimolar amounts of chloroacetamido derivative $\mathbf{1}$ and malononitrile in absolute ethyl alcohol containing a few drops of triethylamine afforded the corresponding condensation product 2-amino-1-(4-antipyrinylthiazol-2-yl)-3-cyano-4,5-dihydro-5-oxo-1H-pyrrole (12) which was identified based on its compatible spectral analyses, see Scheme 4. Thus, the infrared spectrum of compound 12 exhibited the characteristic absorptions at 3293, 3191, 2216, and $1705 \mathrm{~cm}^{-1}$ related to the functional groups amino $\left(\mathrm{NH}_{2}\right)$, nitrile $(\mathrm{C} \equiv \mathrm{N})$, and carbonyl $(\mathrm{C}=\mathrm{O})$, respectively. In the ${ }^{1} \mathrm{H} \mathrm{NMR}$ spectrum, the protons of two methyl, methylene, thiazole-H5, and amino functions were secured by the presence of their characteristic signals at $\delta 2.65 \mathrm{ppm}$ (singlet), $\delta 3.32 \mathrm{ppm}$ (singlet), $\delta 4.36 \mathrm{ppm}$ (singlet), $\delta 7.29 \mathrm{ppm}$ (singlet), and $\delta 12.47 \mathrm{ppm}$ (singlet), respectively.

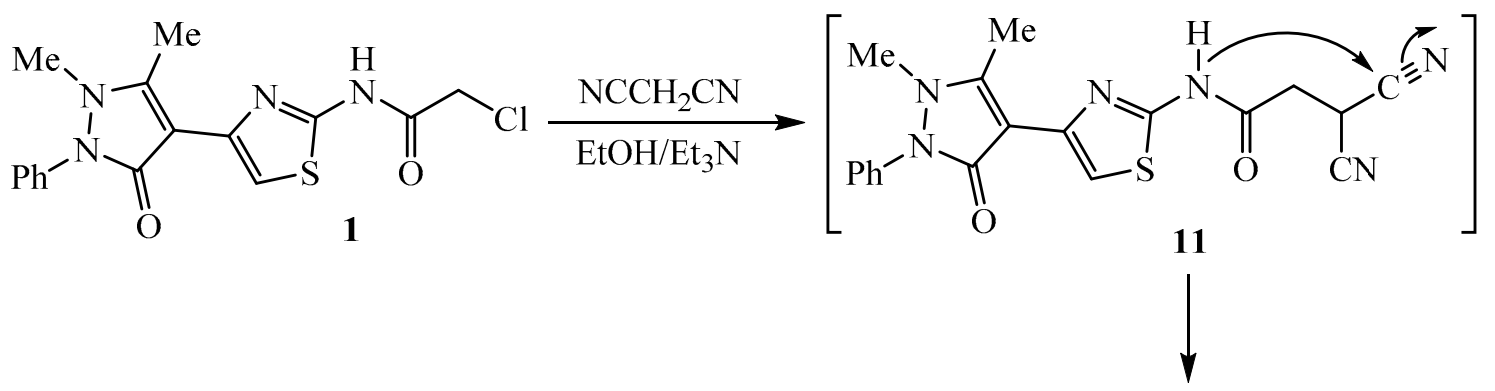<smiles>Cc1c(-c2csc(N3C(=O)CC(C#N)=C3N)n2)c(=O)n(-c2ccccc2)n1C</smiles>

12<smiles>Cc1c(-c2csc(N3C(=N)C(C#N)CC3=O)n2)c(=O)n(-c2ccccc2)n1C</smiles>

$12^{\prime}$

Scheme 4. Reaction of thiazolyl-chloroacetamide $\mathbf{1}$ with malononitrile.

Treatment of chloroacetamide derivative $\mathbf{1}$ with salicylaldehyde in DMSO containing potassium carbonate was achieved by stirring the reaction mixture for $8 \mathrm{~h}$ followed by neutralization with dilute 
$\mathrm{HCl}$ to furnish $\mathrm{N}$-(4-antipyrinylthiazol-2-yl) benzofuran-2-carboxamide (13). It was reasoned that the chlorine atom in acetamido derivative 1 could be substituted by nucleophiles, so the plausible pathway for the formation of benzofuran derivative $\mathbf{1 4}$ could be via formation of intermediate 13, which subsequently underwent a condensation reaction between the formyl and active methylene group, see Scheme 5. The structural proof of compound $\mathbf{1 4}$ was determined based on its correct spectral analyses. Thus, the infrared spectrum of compound 14 showed absorptions at 3369 and $1689 \mathrm{~cm}^{-1}$ to secure the functional groups $(\mathrm{N}-\mathrm{H})$ and $(\mathrm{C}=\mathrm{O})$, respectively. The ${ }^{1} \mathrm{H}$ NMR spectrum clearly indicated the presence of a singlet for three protons at $2.62\left(\mathrm{CH}_{3}-\mathrm{C}\right)$, a singlet for three protons at $3.33\left(\mathrm{CH}_{3}-\mathrm{N}\right)$, a singlet for one proton at $7.28 \mathrm{ppm}$ (thiazole-H5), a multiplet for ten protons in the region of $\delta 7.36-7.71$ ppm (aromatic-H and furan-H3), and a singlet for one proton at $\delta 12.31 \mathrm{ppm}(\mathrm{NH})$.

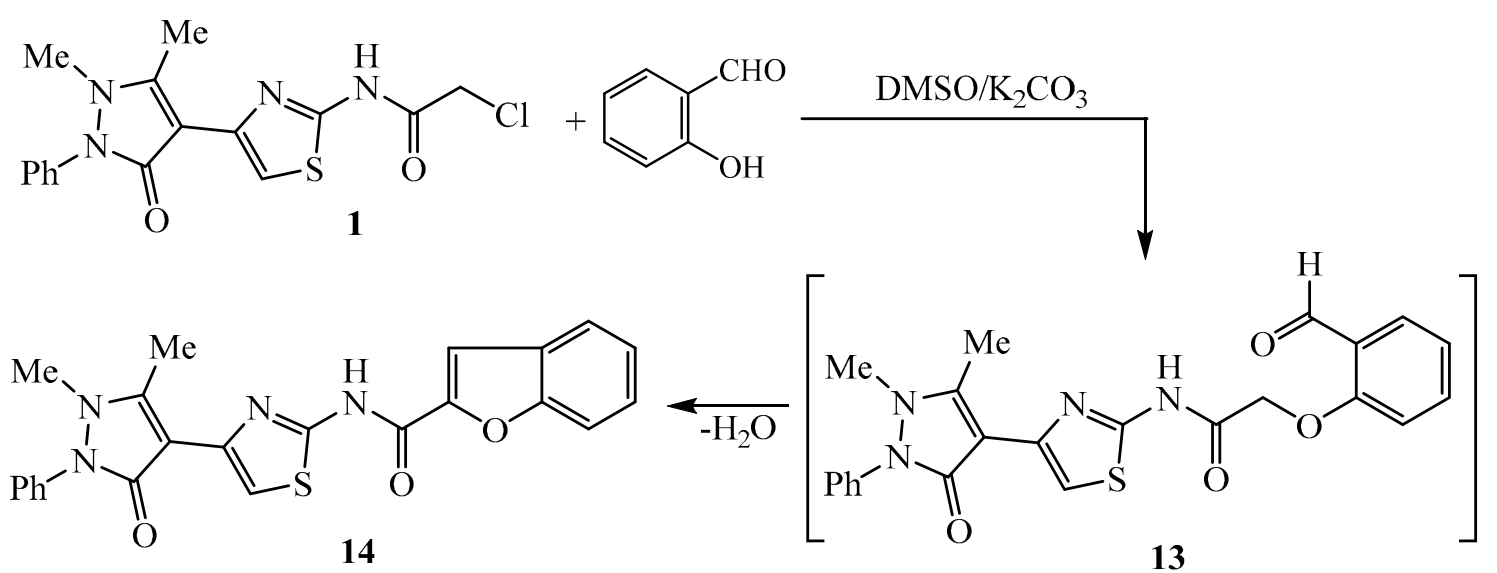

Scheme 5. Reaction of thiazolyl-chloroacetamide $\mathbf{1}$ with salicylaldehyde.

\subsection{Computational Studies}

DMOL3 module calculations were used to examine the cluster estimations [34] and DNP, the double numerical basis sets plus polarization functional (DNP) implemented in the Materials Studio bundle [35]. It is constructed to realize the large-scale density functional theory (DFT) calculations [36-39]. The geometric optimization is performed with no symmetry confinement.

\subsubsection{Geometry Optimization}

The molecular structures along with atomic numbering of the title 4-antipyrinylthiazole scaffolds $(2,4,5,6,7,9,10,12$, and 14) are represented in Figures 1 and 2. The bond lengths and bond angles are included in the supplementary material, Tables S1-S24. The data obtained in these tables reveal that the bond lengths or bond angles are altered to some extent upon the formation of a new thiazole derivative, which is in turn dependent (or influenced) by the nature of the attacking electrophile or the experimental conditions.

\subsubsection{Global Reactivity Descriptors}

Density functional theory (DFT) was utilized to understand the chemical reactivity and site selectivity of the molecular systems. As highest occupied molecular orbital (HOMO) and lowest unoccupied molecular orbital (LUMO) are the orbitals that are the most likely to be involved in chemical reactivity, where the HOMO ( $\pi$ donor) is the highest energy orbital that is still occupied; therefore, energetically, it is the orbital which is easiest to remove electrons from, thus acting as a Lewis base. On the other hand, the LUMO ( $\pi$ acceptor) is the lowest lying orbital that is empty; therefore, energetically, this orbital is the easiest to add more electrons to (acts as Lewis acid). The energy gap $=E H O M O-E L U M O$ and clarifies the inevitable charge exchange interaction inside the molecule. The global electrophilicity index $(\omega)$, chemical potential $(\mu)$, electronegativity $(\chi)$, global softness $(S)$, 
and global hardness ( $\eta)$, are determined by the well-known equations [40] and the data are listed in Table 1.

$$
\begin{gathered}
\chi=-1 / 2\left(E_{\mathrm{LUMO}}+E_{\mathrm{HOMO}}\right) \\
\mu=-\chi=1 / 2\left(E_{\mathrm{LUMO}}+E_{\mathrm{HOMO}}\right) \\
\eta=1 / 2\left(E_{\mathrm{LUMO}}-E_{\mathrm{HOMO}}\right) \\
S=1 / 2 \eta \\
\omega=\mu^{2} / 2 \eta
\end{gathered}
$$

\begin{tabular}{|c|c|c|c|c|c|c|c|c|c|c|}
\hline Cpd. No. & HOMO & LUMO & $\mathrm{E}_{\text {HOMO }}-\mathrm{E}_{\text {LUMO }}$ & $x$ & $\mu$ & $\eta$ & $\mathrm{S}$ & $\omega$ & $\sigma$ & Binding Energy * \\
\hline 4 & -3.389 & -2.232 & -1.157 & 2.810 & -2.810 & 0.578 & 0.864 & 6.827 & 1.728 & -6312.004 \\
\hline 6 & -3.839 & -3.017 & -0.822 & 3.428 & -3.428 & 0.411 & 1.216 & 14.295 & 2.433 & -6204.837 \\
\hline $7 \mathbf{a}$ & -3.759 & -2.934 & -0.825 & 3.346 & -3.346 & 0.412 & 1.212 & 13.574 & 2.424 & -7817.104 \\
\hline $7 b$ & -3.852 & -3.019 & -0.833 & 3.435 & -3.435 & 0.416 & 1.200 & 14.168 & 2.400 & -7859.676 \\
\hline $10 \mathrm{~b}$ & -4.098 & -3.616 & -0.482 & 3.857 & -3.857 & 0.241 & 2.074 & 30.864 & 4.149 & -6271.616 \\
\hline $10 c$ & -3.768 & -2.966 & -0.802 & 3.367 & -3.367 & 0.401 & 1.246 & 14.135 & 2.493 & -6013.436 \\
\hline 12 & -5.005 & -2.237 & -2.768 & 3.621 & -3.621 & 1.384 & 0.361 & 4.736 & 0.722 & -5973.095 \\
\hline 14 & -3.506 & -2.456 & -1.050 & 2.981 & -2.981 & 0.525 & 0.952 & 8.463 & 1.904 & -5768.652 \\
\hline
\end{tabular}

The softness $\sigma=1 / \eta$

Table 1. Calculated global reactivity descriptors for the antipyrinyl-thiazole derivatives.

From the obtained data we can deduced that:

1. The values of Frontier molecular orbitals energies (FMOs) namely $E_{\mathrm{HOMO}}$ and $E_{\mathrm{LUMO}}$ as well as their neighboring orbitals are negative, indicating the stability of the synthesized antipyrinyl-thiazole derivatives [41].

2. Based on FMOs theory, the reaction occurs with maximum overlap between the HOMO on one molecule and the LUMO on the other and this is a controlling factor in many reactions. Therefore, orbitals of the derivative with the largest value of molecular orbital coefficients may be considered as the sites of electron donation. Thus, the HOMO level is mostly localized on $\mathrm{N}(2)$, N(3), S(17), C(16), C(18), C(19), C(4), and O(14) atoms, see Figures 1 and 2, indicating the most preferable sites for attack of the incoming nucleophile.

3. It is well documented that the smaller the energy gap $\left(\mathrm{E}_{\mathrm{HOMO}}-\mathrm{E}_{\mathrm{LUMO}}\right)$ of a molecule the greater the reactivity, polarizability, and readiness to offer electrons to an acceptor and the molecule is considered to be "soft", which in turn affects its biological activity. Thus, the title compounds follow the order: 10b $>10 c>6>7 a>7 b>10 a>5>14>4>9>2>12$. This means that compound $10 \mathrm{~b}$ possesses the smallest energy gap and the highest electrophilicty index $(\omega=30.864)$ among all newly synthesized thiazoles and, therefore, has the highest softness, polarizability, and reactivity [13].

4. Furthermore, it is obvious that the values of the binding energy increase for the new 4 -antipyrinylthiazole derivatives (except thiazole compound 9) when compared to that of the starting compound (i.e., 4-antipyrinyl-2-chloroacetamidothiazole), revealing higher stability of the newly-formed thiazoles. The newly synthesized thiazoles can be arranged according to stability as: $7 \mathrm{~b}>7 \mathrm{a}>10 \mathrm{a}>5>4>10 \mathrm{~b}>6>10 \mathrm{c}>12>14>2>9$. 


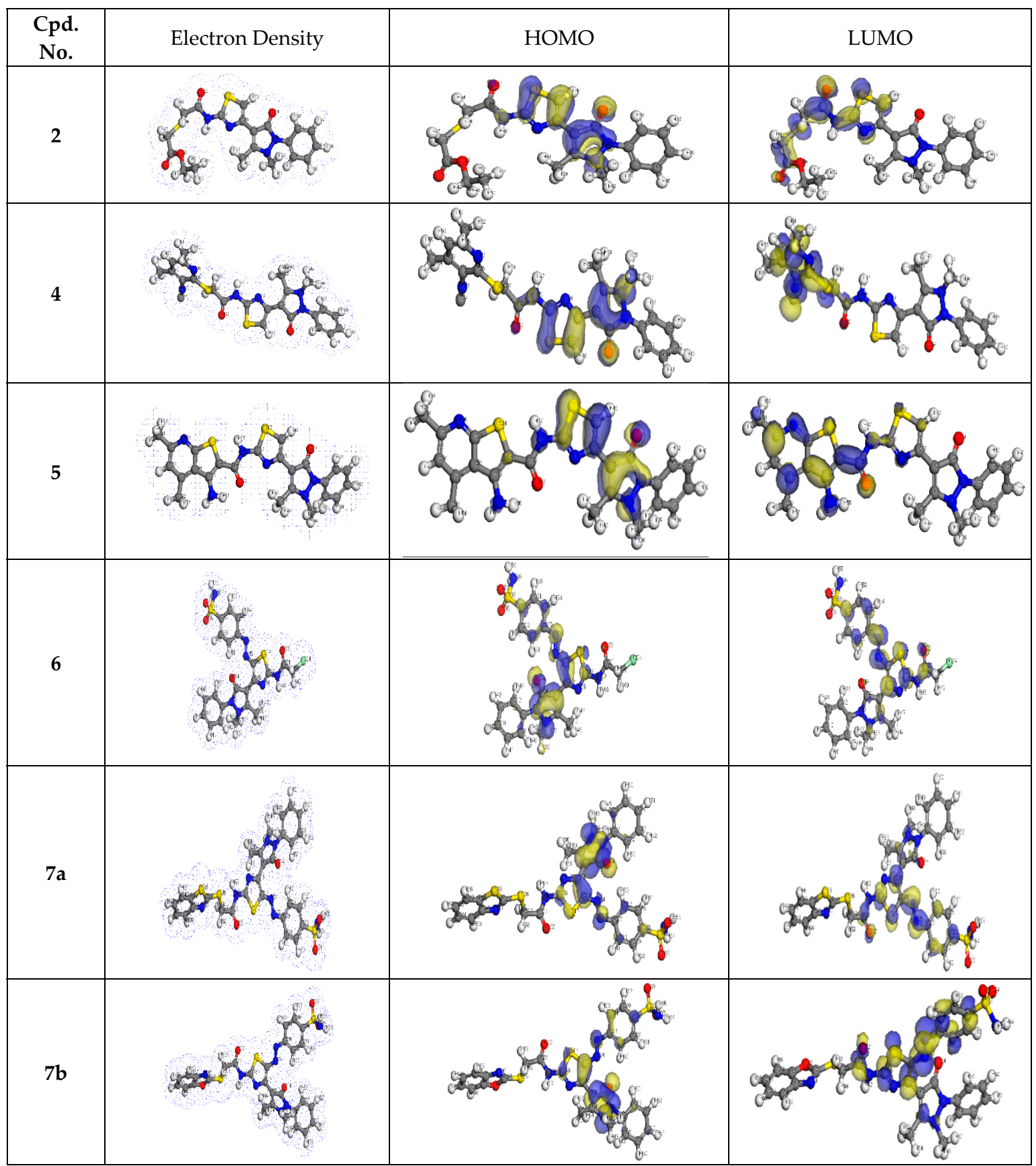

Figure 1. The electron density, the highest occupied molecular orbital (HOMO) and lowest unoccupied molecular orbital (LUMO) frontier orbitals of 4-antipyrinylthiazole derivatives 2, 4, 5, 6, and 7. 


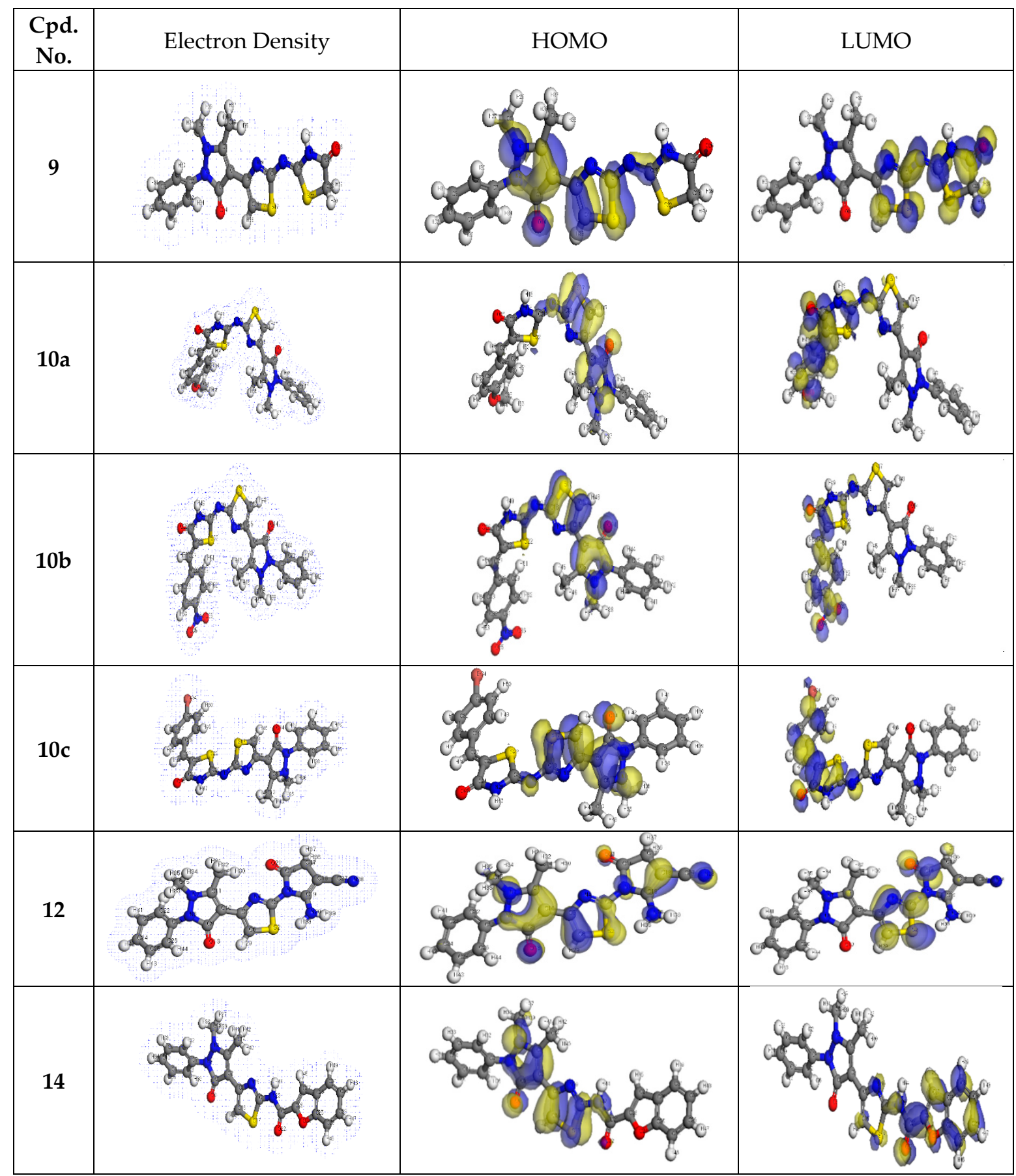

Figure 2. The electron density, the HOMO and LUMO frontier orbitals of 4-antipyrinylthiazole derivatives $9,10,12$, and 14 .

\subsection{Antioxidant Activity}

The antioxidant activity assay was estimated using an ABTS free radical scavenging activity assay (2,2'-azinobis(3-ethylbenzothiazoline-6-sulfonic acid) [42]. Inhibition free radical ABTS in percent (I \%) was calculated as per the equation:

$$
\mathrm{I} \%=\left(\mathrm{A}_{\text {blank }}-\mathrm{A}_{\text {sample }}\right) /\left(\mathrm{A}_{\text {blank }}\right) \times 100
$$

where $A_{\text {blank }}$ is the absorbance of the control reaction (containing all reagents except the test compound), and $\mathrm{A}_{\text {sample }}$ is the absorbance of the test sample. 
The antioxidant activities of the newly synthesized 4-antipyrinylthiazole scaffolds 2, 4, 5, 6, 7, 9, 10, 12, and 14 were evaluated using the ABTS Radical Cation Decolorization Assay [43]. The results, shown in Table 2, indicated that compounds $10 \mathbf{b}, 10 \mathbf{c}$, and $7 \mathbf{a}$ have excellent antioxidant properties compared to the reference of the test (L-Ascorbic acid, 88.88\%). The derivatives of 2-(4-antipyrinylthiazolylamino)-5-substituitedbenzylidene-thiazol-4(5H)-one substituted with electron-withdrawing groups at the benzylidene moiety exhibited the best antioxidant activity. The percentage inhibition of scaffolds $10 \mathrm{~b}$ and $10 \mathrm{c}$ substituted with nitro and bromide groups at the benzylidene moiety are $85.74 \%$ and $83.51 \%$, respectively.

The replacement of the chlorine atom of the 2-chloroacetamido-thiazole compound 6 (percentage inhibition of $73.33 \%$ ) by the benzothiazolyl moiety to afford the corresponding antipyrinyl-thiazole scaffold $7 \mathbf{a}$ enhanced the antioxidant activity with percentage inhibition $78.14 \%$.

Table 2. ABTS scavenging activity of the synthesized 4-antipyrinylthiazole scaffolds.

\begin{tabular}{ccc}
\hline Compound Number & Absorbance & ABTS Inhibition (\%) \\
\hline Control of ABTS & 0.540 & 0 \\
L-Ascorbic acid & 0.060 & 88.88 \\
$\mathbf{2}$ & 0.306 & 43.33 \\
$\mathbf{4}$ & 0.274 & 49.25 \\
$\mathbf{5}$ & 0.219 & 59.44 \\
$\mathbf{6}$ & 0.144 & 73.33 \\
$\mathbf{7 a}$ & 0.118 & 78.14 \\
$\mathbf{7 b}$ & 0.223 & 58.70 \\
$\mathbf{9}$ & 0.211 & 60.92 \\
$\mathbf{1 0 a}$ & 0.182 & 66.29 \\
$\mathbf{1 0 b}$ & 0.077 & 85.74 \\
$\mathbf{1 0 c}$ & 0.089 & 83.51 \\
$\mathbf{1 2}$ & 0.347 & 35.74 \\
$\mathbf{1 4}$ & 0.212 & 60.74 \\
\hline
\end{tabular}

\section{Materials and Methods}

\subsection{General Methods}

Melting points have been determined on Gallenkamp electric apparatus (capillary method, Gallenkamp Co., London, UK). IR spectra (KBr discs) have been obtained on a Mattson 5000 FT-IR spectrometer (Shimadzu Co., Kyoto, Japan). The nuclear magnetic resonance spectra have been recorded using a WP 300 spectrometer (Bruker Co., Billerica, MA, USA) at $300 \mathrm{MHz}$ for ${ }^{1} \mathrm{H}-\mathrm{NMR}$ or $75.5 \mathrm{MHz}$ for ${ }^{13} \mathrm{C}-\mathrm{NMR}$. The mass analysis (EI technique, $70 \mathrm{eV}$ ) was acquired by a Qp-2010 mass spectrometer (Shimadzu, Tokyo, Japan).

\subsection{Preparation of Ethyl 2-[(2-((4-antipyrinylthiazol-2-yl)amino)-2-oxoethyl)-thio]acetate (2)}

A suspension of chloroacetamido derivative $\mathbf{1}(2 \mathrm{mmol}, 0.72 \mathrm{~g})$ and ethyl thioglycolate $(2 \mathrm{mmol}$, $0.24 \mathrm{~mL})$ in $15 \mathrm{~mL}$ ethyl alcohol containing $\mathrm{CH}_{3} \mathrm{COONa}(0.2 \mathrm{~g})$ was heated under reflux for $3 \mathrm{~h}$. The resulting precipitate upon cooling was filtered, dried, and recrystallized from EtOH to furnish the sulfide compound 2. White solid, yield $=84 \%$, m.p. $=161-163^{\circ} \mathrm{C} . \mathrm{IR}\left(\bar{v} / \mathrm{cm}^{-1}\right): 3195(\mathrm{~N}-\mathrm{H}), 1723$ $(\mathrm{C}=\mathrm{O}), 1682(\mathrm{C}=\mathrm{O}) .{ }^{1} \mathrm{H}-\mathrm{NMR}\left(\mathrm{CDCl}_{3}\right): \delta 1.22\left(\mathrm{t}, J=7.15 \mathrm{~Hz}, 3 \mathrm{H}, \mathrm{CH}_{3}\right), 2.66\left(\mathrm{~s}, 3 \mathrm{H}, \mathrm{CH}_{3}\right), 3.16(\mathrm{~s}, 3 \mathrm{H}$, $\left.\mathrm{CH}_{3}\right), 3.32\left(\mathrm{~s}, 2 \mathrm{H}, \mathrm{CH}_{2}\right), 3.64\left(\mathrm{~s}, 2 \mathrm{H}, \mathrm{CH}_{2}\right), 4.12\left(\mathrm{q}, J=7.15 \mathrm{~Hz}, 2 \mathrm{H}, \mathrm{CH}_{2}\right), 7.08(\mathrm{~s}, 1 \mathrm{H}$, thiazole-H5), 7.26-7.52 (m, 5H, Ar-H), $11.24(\mathrm{~s}, 1 \mathrm{H}, \mathrm{NH}) .{ }^{13} \mathrm{C}-\mathrm{NMR}\left(\mathrm{CDCl}_{3}\right): \delta 12.48,14.02,34.28,35.16,36.37,61.68$, $104.23,109.18,124.44$ (2C), 126.87, 129.31 (2C), 135.08, 142.67, 151.92, 156.41, 163.85, 164.91, 170.67. Analysis for $\mathrm{C}_{20} \mathrm{H}_{22} \mathrm{~N}_{4} \mathrm{O}_{4} \mathrm{~S}_{2}$ (446): Calcd.: C, 53.80; H, 4.97; N, 12.55\%. Found: C, 53.89; H, 4.94; $\mathrm{N}, 12.50 \%$. 


\subsection{Preparation of N-(4-antipyrinylthiazol-2-yl)-2-((3-cyano-4,6-dimethylpyridin-2-yl)thio)-acetamide (4)}

To a stirred suspension of 3-cyano-4,6-dimethylpyridine-2-thiol ( $0.82 \mathrm{~g}, 0.005 \mathrm{~mol})$ and anhydrous $\mathrm{K}_{2} \mathrm{CO}_{3}(0.70 \mathrm{~g}, 0.005 \mathrm{~mol})$ in $40 \mathrm{~mL}$ acetone, 4-antipyrinyl-2-chloroacetamidothiazole $(1.81 \mathrm{~g}, 0.005 \mathrm{~mol})$ was added. The reaction suspension was heated under reflux for two $\mathrm{h}$ and then cooled to $25^{\circ} \mathrm{C}$. The solid, obtained after dilution by $20 \mathrm{~mL}$ cold water, was filtered and dried. Recrystallization was achieved by heating in ethanol. Yellow crystals, yield $=80 \%$, m.p. $178-180{ }^{\circ} \mathrm{C}$. IR $\left(\bar{v} / \mathrm{cm}^{-1}\right): 3371$ $(\mathrm{N}-\mathrm{H}), 2219(\mathrm{C} \equiv \mathrm{N}), 1688(\mathrm{C}=\mathrm{O}) .{ }^{1} \mathrm{H}-\mathrm{NMR}\left(\mathrm{CDCl}_{3}\right): \delta 2.41\left(\mathrm{~s}, 6 \mathrm{H}, 2 \mathrm{CH}_{3}\right), 2.64\left(\mathrm{~s}, 3 \mathrm{H}, \mathrm{CH}_{3}\right), 3.33(\mathrm{~s}, 3 \mathrm{H}$, $\left.\mathrm{CH}_{3}\right), 4.05\left(\mathrm{~s}, 2 \mathrm{H}, \mathrm{CH}_{2}\right), 7.05\left(\mathrm{~s}, 1 \mathrm{H}\right.$, pyridine- $\left.\mathrm{H}_{5}\right), 7.21\left(\mathrm{~s}, 1 \mathrm{H}\right.$, thiazole- $\left.\mathrm{H}_{5}\right), 7.31-7.55(\mathrm{~m}, 5 \mathrm{H}, \mathrm{Ar}-\mathrm{H})$, $12.14(\mathrm{~s}, 1 \mathrm{H}, \mathrm{CONH}) .{ }^{13} \mathrm{C}-\mathrm{NMR}\left(\mathrm{CDCl}_{3}\right): \delta 12.44,20.00,24.53,34.49,40.26,104.70,105.81,112.31,119.78$, 124.23, 126.16 (2C), 127.74, 129.51 (2C), 133.81, 142.42, 151.68, 155.62, 157.74, 158.26, 160.37, 163.38, 164.91. Analysis for $\mathrm{C}_{24} \mathrm{H}_{22} \mathrm{~N}_{6} \mathrm{O}_{2} \mathrm{~S}_{2}$ (490): Calcd.: C, 58.76; $\mathrm{H}, 4.52 ; \mathrm{N}, 17.13 \%$. Found: C, 58.82; H, 4.50; N, $17.06 \%$.

\subsection{Synthesis of 3-amino-N-(4-antipyrinylthiazol-2-yl)-4,6-dimethylthieno[2,3-b]pyridine-2-carboxamide (5)}

The sulfide derivative $4(0.98 \mathrm{~g}, 0.002 \mathrm{~mol})$ was heated under reflux in sodium ethoxide solution (prepared by stirring small parts of $0.08 \mathrm{~g}$ sodium metal in $20 \mathrm{~mL}$ dry ethyl alcohol) for $2 \mathrm{~h}$. The reaction mixture was cooled, then poured into ice-cold water and neutralized with $0.1 \mathrm{~N} \mathrm{HCl}$. The obtained solid was filtered and recrystallized from ethyl alcohol. Yellow crystals, yield $=54 \%$, m.p. $=271-273{ }^{\circ} \mathrm{C}$. IR $\left(\bar{v} / \mathrm{cm}^{-1}\right): 3412,3353,3184\left(\mathrm{~N}-\mathrm{H}\right.$ and $\left.\mathrm{NH}_{2}\right), 1658(\mathrm{C}=\mathrm{O}) .{ }^{1} \mathrm{H}-\mathrm{NMR}\left(\mathrm{DMSO}-d_{6}\right): \delta 2.43\left(\mathrm{~s}, 6 \mathrm{H}, 2 \mathrm{CH}_{3}\right)$, $2.68\left(\mathrm{~s}, 3 \mathrm{H}, \mathrm{CH}_{3}\right), 3.34\left(\mathrm{~s}, 3 \mathrm{H}, \mathrm{CH}_{3}\right), 6.92\left(\mathrm{~s}, 2 \mathrm{H}, \mathrm{NH}_{2}\right), 7.04\left(\mathrm{~s}, 1 \mathrm{H}\right.$, pyridine- $\left.\mathrm{H}_{5}\right), 7.26\left(\mathrm{~s}, 1 \mathrm{H}\right.$, thiazole- $\left.\mathrm{H}_{5}\right)$, 7.34-7.58 (m, 5H, Ar-H), 12.38 ppm (s, 1H, CONH). ${ }^{13} \mathrm{C}-\mathrm{NMR}$ (DMSO-d 6 ): $\delta 12.58,20.33,23.68,34.16$, 98.74, 107.86, 109.47, 118.63, 122.03, 126.13 (2C), 128.81, 129.49 (2C), 133.14, 143.56, 145.42, 154.50, 159.27, 160.49, 162.41, 163.83, 164.43, 166.32. Analysis for $\mathrm{C}_{24} \mathrm{H}_{22} \mathrm{~N}_{6} \mathrm{O}_{2} \mathrm{~S}_{2}$ (490): Calcd.: C, 58.76; $\mathrm{H}, 4.52$; $\mathrm{N}, 17.13 \%$. Found: C, 58.62; H, 4.58; N, 17.24\%.

\subsection{Synthesis of 4-antipyrinyl-2-chloroacetamido-5-(4-sulfamoylphenylazo)thiazole (6)}

A cold suspension of sulphanilamide $(10 \mathrm{mmol}, 1.70 \mathrm{~g})$ in concentrated $\mathrm{HCl}(3 \mathrm{~mL})$ was diazotized at $0-5{ }^{\circ} \mathrm{C}$ with a solution of $\mathrm{NaNO}_{2}\left(0.70 \mathrm{~g}\right.$ in $\left.10 \mathrm{~mL} \mathrm{H} \mathrm{H}_{2} \mathrm{O}\right)$ with stirring for $30 \mathrm{~min}$. The diazonium solution was added dropwise to a mixture of chloroacetamide derivative $\mathbf{1}$ (10 mmol, $3.62 \mathrm{~g}$ ) and sodium acetate $(3 \mathrm{~g})$ in $35 \mathrm{~mL}$ ethanol with stirring in an ice-bath for $1 \mathrm{~h}$. The precipitate was filtered and recrystallized from EtOH/DMF mixture (5:1) to give the sulfamoylphenylazo-thiazole derivative 6. Reddish-brown solid, yield $=74 \%$, m.p. $=241-242{ }^{\circ} \mathrm{C} . \mathrm{IR}\left(\bar{v} / \mathrm{cm}^{-1}\right): 3351,3264\left(\mathrm{NH}_{2}\right.$ and N-H), $1697 \mathrm{~cm}^{-1}(\mathrm{C}=\mathrm{O}) .{ }^{1} \mathrm{H}-\mathrm{NMR}\left(\mathrm{DMSO}-d_{6}\right): \delta 2.72\left(\mathrm{~s}, 3 \mathrm{H}, \mathrm{CH}_{3}\right), 3.28\left(\mathrm{~s}, 3 \mathrm{H}, \mathrm{CH}_{3}\right), 4.44(\mathrm{~s}, 2 \mathrm{H}$, $\left.\mathrm{CH}_{2}\right), 7.28-7.61\left(\mathrm{~m}, 7 \mathrm{H}, \mathrm{Ar}-\mathrm{H}\right.$ and $\left.\mathrm{NH}_{2}\right), 7.94-8.00(\mathrm{dd}, 4 \mathrm{H}, \mathrm{Ar}-\mathrm{H}), 12.92 \mathrm{ppm}(\mathrm{s}, 1 \mathrm{H}, \mathrm{NH}) .{ }^{13} \mathrm{C}-\mathrm{NMR}$ (DMSO-d ${ }_{6}$ ): $\delta$ 12.57, 35.16, 42.11, 108.81, 121.58, 124.41 (2C), 127.08 (2C), 129.21 (2C), 129.79 (2C), 132.25, 135.81, 140.27, 142.72, 147.47, 155.53, 161.21, 162.78, 165.31. Analysis for $\mathrm{C}_{22} \mathrm{H}_{20} \mathrm{ClN}_{7} \mathrm{O}_{4} \mathrm{~S}_{2}$ (545): Calcd.: C, $48.39 ; \mathrm{H}, 3.69 ; \mathrm{N}, 17.96 \%$. Found: C, 48.27; H, 3.63; N, 17.85\%.

\subsection{Preparation of 2-substituted-N-(5-((4-sulfamoylphenyl)azo)thiazol-2-yl)acetamide Derivatives 7}

A suspension of compound 6 ( $1 \mathrm{mmol}, 0.54 \mathrm{~g})$, 2-mercaptobenzothiazole or 2-mercaptobenzoxazole ( $1 \mathrm{mmol}$ ) and $\mathrm{CH}_{3} \mathrm{COONa}(0.16 \mathrm{~g})$ was heated under reflux in $15 \mathrm{~mL}$ ethyl alcohol for $2 \mathrm{~h}$; after which, the formed precipitate upon cooling was filtered, washed by cold ethanol, and dried to give the anticipated compounds $7 \mathbf{a}$ and $7 \mathbf{b}$, respectively.

2-(Benzothiazol-2-ylthio)-N-(5-((4-sulfamoylphenyl)azo)-4-antipyrinylthiazol-2-yl)acetamide (7a). Brown solid, yield $=72 \%$, m.p. $=285-287^{\circ} \mathrm{C} . \mathrm{IR}\left(\bar{v} / \mathrm{cm}^{-1}\right): 3341,3257\left(\mathrm{NH}_{2}\right.$ and N-H), $1705 \mathrm{~cm}^{-1}(\mathrm{C}=\mathrm{O})$. ${ }^{1} \mathrm{H}-\mathrm{NMR}\left(\mathrm{DMSO}-d_{6}\right): \delta 2.75\left(\mathrm{~s}, 3 \mathrm{H}, \mathrm{CH}_{3}\right), 3.36\left(\mathrm{~s}, 3 \mathrm{H}, \mathrm{CH}_{3}\right), 4.42\left(\mathrm{~s}, 2 \mathrm{H}, \mathrm{CH}_{2}\right), 7.32-7.94(\mathrm{~m}, 15 \mathrm{H}$, Ar-H and $\left.\mathrm{NH}_{2}\right), 12.76 \mathrm{ppm}(\mathrm{s}, 1 \mathrm{H}, \mathrm{NH})$. MS (EI): $m / z(\%)=676$ (molecular ion, 13.8\%). Analysis for $\mathrm{C}_{29} \mathrm{H}_{24} \mathrm{~N}_{8} \mathrm{O}_{4} \mathrm{~S}_{4}$ (676): Calcd.: C, 51.47; H, 3.57; N, 16.56\%. Found: C, 51.68; H, 3.66; N, 16.68\%. 
2-(Benzoxazol-2-ylthio)-N-(5-((4-sulfamoylphenyl)azo)-4-antipyrinylthiazol-2-yl)acetamide (7b). Brown solid, yield $=64 \%$, m.p. $=274-275^{\circ} \mathrm{C} . \mathrm{IR}\left(\bar{v} / \mathrm{cm}^{-1}\right): 3336,3248\left(\mathrm{NH}_{2}\right.$ and $\left.\mathrm{N}-\mathrm{H}\right), 1699 \mathrm{~cm}^{-1}(\mathrm{C}=\mathrm{O})$. ${ }^{1} \mathrm{H}-\mathrm{NMR}$ (DMSO- $\left.d_{6}\right): \delta 2.68\left(\mathrm{~s}, 3 \mathrm{H}, \mathrm{CH}_{3}\right), 3.33\left(\mathrm{~s}, 3 \mathrm{H}, \mathrm{CH}_{3}\right), 4.41\left(\mathrm{~s}, 2 \mathrm{H}, \mathrm{CH}_{2}\right), 7.40-7.92(\mathrm{~m}, 15 \mathrm{H}, \mathrm{Ar}-\mathrm{H}$ and $\left.\mathrm{NH}_{2}\right), 12.86(\mathrm{~s}, 1 \mathrm{H}, \mathrm{NH})$. MS (EI): $m / z(\%)=660$ (molecular ion, $21.2 \%$ ). Analysis for $\mathrm{C}_{29} \mathrm{H}_{24} \mathrm{~N}_{8} \mathrm{O}_{5} \mathrm{~S}_{3}$ (660): Calcd.: C, 52.72; H, 3.66; N, 16.96\%. Found: C, 52.90; H, 3.58; N, 17.07\%.

\subsection{Preparation of 2-((4-antipyrinylthiazol-2-yl)imino)thiazolidin-4-one (9)}

A solution of chloroacetamido derivative $1(10 \mathrm{mmol}, 3.62 \mathrm{~g})$ and ammonium thiocyanate $(15 \mathrm{mmol}, 1.14 \mathrm{~g})$ in $20 \mathrm{~mL}$ ethanol was heated under reflux for $5 \mathrm{~h}$. The precipitate that formed upon cooling was isolated by filtration and recrystallized from EtOH to furnish thiazolidin-4-one derivative 9. Yellow solid, yield $=80 \%$, m.p. $=201-202{ }^{\circ} \mathrm{C}$. IR $\left(\bar{v} / \mathrm{cm}^{-1}\right): 3128(\mathrm{~N}-\mathrm{H}), 1714(\mathrm{C}=\mathrm{O})$. ${ }^{1} \mathrm{H}-\mathrm{NMR}$ (DMSO- $\left.d_{6}\right): \delta 2.65\left(\mathrm{~s}, 3 \mathrm{H}, \mathrm{CH}_{3}\right), 3.31\left(\mathrm{~s}, 3 \mathrm{H}, \mathrm{CH}_{3}\right), 4.05\left(\mathrm{~s}, 2 \mathrm{H}, \mathrm{CH}_{2}\right), 7.31-7.60(\mathrm{~m}, 6 \mathrm{H}$, Ar-H and thiazole-H5), 12.06 (s, $1 \mathrm{H}, \mathrm{NH}) .{ }^{13} \mathrm{C}-\mathrm{NMR}$ (DMSO- $\left.d_{6}\right): \delta 11.80,33.76,35.48,104.51,108.71$, 122.66 (2C), 124.71, 128.31 (2C), 133.64, 141.46, 151.48, 159.24, 162.66, 165.29, 174.39. Analysis for $\mathrm{C}_{17} \mathrm{H}_{15} \mathrm{~N}_{5} \mathrm{O}_{2} \mathrm{~S}_{2}$ (385): Calcd.: C, 52.97; H, 3.92; N, 18.17\%. Found: $\mathrm{C}, 52.86 ; \mathrm{H}, 3.95 ; \mathrm{N}, 18.21 \%$.

\subsection{Synthesis of 2-((4-antipyrinylthiazol-2-yl)imino)-5-arylidenethiazolidin-4-one Derivatives 10a-c}

A suspension of thiazolidin-4-one derivative $9(2 \mathrm{mmol}, 0.77 \mathrm{~g})$ and the appropriate para-substituted benzaldehyde derivative $(2 \mathrm{mmol})$ in $15 \mathrm{~mL}$ glacial $\mathrm{CH}_{3} \mathrm{COOH}$ containing $0.5 \mathrm{~g}$ fused $\mathrm{CH}_{3} \mathrm{COONa}$ was heated under reflux for $4 \mathrm{~h}$. The reaction mixture was cooled and then poured into ice-water and the precipitate was filtered and recrystallized from ethanol.

2-((4-Antipyrinylthiazol-2-yl)imino)-5-(4-methoxybenzylidene)thiazolidin-4-one (10a). Yellow powder, yield $=74 \%$, m.p. $=241-243^{\circ} \mathrm{C}$. IR $\left(\bar{v} / \mathrm{cm}^{-1}\right): 3176(\mathrm{~N}-\mathrm{H}), 1698(\mathrm{C}=\mathrm{O}) .{ }^{1} \mathrm{H}-\mathrm{NMR}\left(\mathrm{DMSO}-d_{6}\right): \delta 2.61(\mathrm{~s}$, $\left.3 \mathrm{H}, \mathrm{CH}_{3}\right), 3.28\left(\mathrm{~s}, 3 \mathrm{H}, \mathrm{CH}_{3}\right), 3.84\left(\mathrm{~s}, 3 \mathrm{H}, \mathrm{OCH}_{3}\right), 7.14(\mathrm{~d}, \mathrm{~J}=8.80 \mathrm{~Hz}, 2 \mathrm{H}, \mathrm{Ar}-\mathrm{H}), 7.28-7.62(\mathrm{~m}, 8 \mathrm{H}, \mathrm{Ar}-\mathrm{H}$ and thiazole-H5), $7.73(\mathrm{~s}, 1 \mathrm{H}$, olefinic $\mathrm{CH}=\mathrm{C}), 12.62(\mathrm{~s}, 1 \mathrm{H}, \mathrm{NH}) .{ }^{13} \mathrm{C}-\mathrm{NMR}$ (DMSO- $\left.d_{6}\right): \delta 12.45,34.36$, 55.18, 106.26, 113.87 (2C), 117.37, 122.41, 123.32 (2C), 127.35, 129.49 (2C), 130.31 (2C), 133.89, 142.26, 145.60, 151.05, 155.83, 159.07, 161.71, 162.66, 164.09, 167.63. Analysis for $\mathrm{C}_{25} \mathrm{H}_{21} \mathrm{~N}_{5} \mathrm{O}_{3} \mathrm{~S}_{2}$ (503): Calcd.: C, 59.63; H, 4.20; N, 13.91\%. Found: C, 59.46; H, 4.26; N, 13.98\%.

2-((4-Antipyrinylthiazol-2-yl)imino)-5-(4-nitrobenzylidene)thiazolidin-4-one (10b). Orange solid, yield $=69 \%$, m.p. $=294-295^{\circ} \mathrm{C} . \mathrm{IR}\left(\bar{v} / \mathrm{cm}^{-1}\right): 3192(\mathrm{~N}-\mathrm{H}), 1718(\mathrm{C}=\mathrm{O}) .{ }^{1} \mathrm{H}-\mathrm{NMR}\left(\mathrm{DMSO}-d_{6}\right): \delta 2.64(\mathrm{~s}, 3 \mathrm{H}$, $\left.\mathrm{CH}_{3}\right), 3.31\left(\mathrm{~s}, 3 \mathrm{H}, \mathrm{CH}_{3}\right), 7.31-7.60(\mathrm{~m}, 6 \mathrm{H}, \mathrm{Ar}-\mathrm{H}$ and thiazole-H5), $7.78(\mathrm{~s}, 1 \mathrm{H}$, olefinic $\mathrm{CH}=\mathrm{C}), 7.82(\mathrm{~d}, J$ $=8.80 \mathrm{~Hz}, 2 \mathrm{H}, \mathrm{Ar}-\mathrm{H}), 8.30(\mathrm{~d}, J=8.40 \mathrm{~Hz}, 2 \mathrm{H}, \mathrm{Ar}-\mathrm{H}), 12.56(\mathrm{~s}, 1 \mathrm{H}, \mathrm{NH}) . \mathrm{MS} m / z(\%): 518\left(\mathrm{M}^{+}, 47.4 \%\right)$. ${ }^{13} \mathrm{C}-\mathrm{NMR}$ (DMSO- $d_{6}$ ): $\delta 12.58,34.19,108.62,116.45,121.09,123.27(2 \mathrm{C}), 124.81(2 \mathrm{C}), 125.48,129.16(2 \mathrm{C})$, 130.34 (2C), 135.27, 139.96, 142.18, 147.29, 151.06, 156.41, 160.20, 161.38, 165.29, 168.40. MS (EI): $\mathrm{m} / \mathrm{z}(\%)$ $=518$ (molecular ion, 65.7\%). Analysis for $\mathrm{C}_{24} \mathrm{H}_{18} \mathrm{~N}_{6} \mathrm{O}_{4} \mathrm{~S}_{2}$ (518): Calcd:: C, 55.59; $\mathrm{H}, 3.50 ; \mathrm{N}, 16.21 \%$. Found: C, 55.77; H, 3.42; N, 16.09\%.

2-((4-Antipyrinylthiazol-2-yl)imino)-5-(4-bromobenzylidene)thiazolidin-4-one (10c). Yellow solid, yield $=83 \%$, m.p. $=275-276{ }^{\circ} \mathrm{C} . \mathrm{IR}\left(\bar{v} / \mathrm{cm}^{-1}\right): 3132(\mathrm{~N}-\mathrm{H}), 1702(\mathrm{C}=\mathrm{O}) .{ }^{1} \mathrm{H}-\mathrm{NMR}\left(\mathrm{DMSO}-d_{6}\right): \delta 2.62(\mathrm{~s}$, $\left.3 \mathrm{H}, \mathrm{CH}_{3}\right), 3.32\left(\mathrm{~s}, 3 \mathrm{H}, \mathrm{CH}_{3}\right), 7.28(\mathrm{~s}, 1 \mathrm{H}$, thiazole- $\mathrm{H} 5), 7.36-7.78(\mathrm{~m}, 10 \mathrm{H}, \mathrm{Ar}-\mathrm{H}$ and olefinic $\mathrm{CH}=\mathrm{C})$, $12.48(\mathrm{~s}, 1 \mathrm{H}, \mathrm{NH}) .{ }^{13} \mathrm{C}-\mathrm{NMR}\left(\mathrm{DMSO}-d_{6}\right): \delta 12.67,34.49,108.57,114.72,120.30,122.75,124.92(2 \mathrm{C})$, 125.16, 128.38 (2C), 129.64 (2C), 131.06 (2C), 133.29, 143.04, 148.38, 151.36, 155.91, 160.47, 161.84, 164.85, 167.76. MS (EI): $m / z(\%)=551$ (molecular ion, $\mathrm{Br}-79,73.4 \%)$ and $553\left(\mathrm{M}^{+}, \mathrm{Br}-81,75.6 \%\right)$. Analysis for $\mathrm{C}_{24} \mathrm{H}_{18} \mathrm{BrN}_{5} \mathrm{O}_{2} \mathrm{~S}_{2}$ (552): Calcd.: $\mathrm{C}, 52.18 ; \mathrm{H}, 3.28 ; \mathrm{N}, 12.68 \%$. Found: $\mathrm{C}, 52.39 ; \mathrm{H}, 3.21 ; \mathrm{N}, 12.81 \%$.

\subsection{Synthesis of 2-amino-1-(4-antipyrinylthiazol-2-yl)-3-cyano-4,5-dihydro-5-oxo-1H-pyrrole (12)}

To a suspension of chloroacetamido derivative 1 ( $2 \mathrm{mmol}, 0.72 \mathrm{~g}$ ) and malononitrile ( $2 \mathrm{mmol}$, $0.13 \mathrm{~g}$ ) in $20 \mathrm{~mL}$ ethanol, five drops of $\mathrm{Et}_{3} \mathrm{~N}$ were added, then the reaction mixture was heated under reflux for $2 \mathrm{~h}$; after which, the reaction mixture was left to cool at room temperature and neutralized with dilute $\mathrm{HCl}$. The precipitate was filtered and recrystallized from $\mathrm{EtOH}$ to afford thiazolyl-pyrrole derivative 12. Orange solid, yield $=52 \%$, m.p. $=284-285^{\circ} \mathrm{C} . \mathrm{IR}\left(\bar{v} / \mathrm{cm}^{-1}\right): 3293,3191\left(\mathrm{NH}_{2}\right), 2216$ 
$(\mathrm{C} \equiv \mathrm{N}), 1705(\mathrm{C}=\mathrm{O}) .{ }^{1} \mathrm{H}-\mathrm{NMR}\left(\mathrm{DMSO}-d_{6}\right): \delta 2.65\left(\mathrm{~s}, 3 \mathrm{H}, \mathrm{CH}_{3}\right), 3.32\left(\mathrm{~s}, 3 \mathrm{H}, \mathrm{CH}_{3}\right), 4.36\left(\mathrm{~s}, 2 \mathrm{H}, \mathrm{CH}_{2}\right), 7.26$ (s, 1H, thiazole-H5), 7.34-7.58 (m, 5H, Ar-H), $12.47 \mathrm{ppm}\left(\mathrm{s}, 2 \mathrm{H}, \mathrm{NH}_{2}\right) .{ }^{13} \mathrm{C}-\mathrm{NMR}$ (DMSO- $\left.d_{6}\right): \delta 11.69$, 29.26, 34.41, 64.21, 102.79, 107.82, 113.76, 123.48 (2C), 126.14, 128.25 (2C), 134.23, 141.61, 150.97, 152.19, 155.47, 159.36, 164.73. Analysis for $\mathrm{C}_{19} \mathrm{H}_{16} \mathrm{~N}_{6} \mathrm{O}_{2} \mathrm{~S}$ (392): Calcd.: $\mathrm{C}, 58.15 ; \mathrm{H}, 4.11 ; \mathrm{N}, 21.42 \%$. Found: $\mathrm{C}$, $58.10 ; \mathrm{H}, 4.15 ; \mathrm{N}, 21.33 \%$.

\subsection{Synthesis of N-(4-antipyrinylthiazol-2-yl)benzofuran-2-carboxamide (14)}

A solution of chloroacetamido derivative $1(2 \mathrm{mmol}, 0.72 \mathrm{~g})$ and salicylaldehyde $(2 \mathrm{mmol}$, $0.21 \mathrm{~mL})$ in $15 \mathrm{~mL}$ DMSO containing anhydrous potassium carbonate $(2 \mathrm{mmol}, 0.28 \mathrm{~g})$ was stirred at room temperature for $8 \mathrm{~h}$; after which, the reaction mixture was poured into ice-cooled water and neutralized by diluted $\mathrm{HCl}$. The precipitate was filtered off and recrystallized from methanol to afford thiazolyl-benzofuran derivative 14. Grey solid, yield $=64 \%$, m.p. $=187-188^{\circ} \mathrm{C} . \mathrm{IR}\left(\bar{v} / \mathrm{cm}^{-1}\right): 3369$ $(\mathrm{N}-\mathrm{H}), 1689(\mathrm{C}=\mathrm{O}) .{ }^{1} \mathrm{H}-\mathrm{NMR}\left(\mathrm{DMSO}-d_{6}\right): \delta 2.62\left(\mathrm{~s}, 3 \mathrm{H}, \mathrm{CH}_{3}\right), 3.33\left(\mathrm{~s}, 3 \mathrm{H}, \mathrm{CH}_{3}\right), 7.28(\mathrm{~s}, 1 \mathrm{H}$, thiazole-H5), 7.36-7.71 (m, 10H, Ar-H and furan-H3), 12.31 (s, $1 \mathrm{H}, \mathrm{NH}) .{ }^{13} \mathrm{C}-\mathrm{NMR}$ (DMSO- $\left.d_{6}\right): \delta 12.24,34.35,106.75$, 108.84, 112.36, 115.27, 120.04, 122.17, 122.58 (2C), 123.80, 124.91, 127.38, 129.11 (2C), 133.39, 143.64, 151.48, 155.08, 157.42, 159.88, 161.40, 163.71. Analysis for $\mathrm{C}_{23} \mathrm{H}_{18} \mathrm{~N}_{4} \mathrm{O}_{3} \mathrm{~S}$ (430): Calcd.: C, 64.17; H, 4.21; N, 13.02\%. Found: C, 64.29; H, 4.16; N, 13.11\%.

\subsection{Anti-Oxidant Activity Screening Assay-ABTS Method}

The 4-antipyrinylthiazole scaffolds $2,4,5,6,7,9,10,12$, and 14 were tested in vitro for their antioxidant activity by ABTS method [43].

\section{Conclusions}

Twelve 4-antipyrinyl-thiazole derivatives were synthesized from the readily available 4-antipyrinyl-2-chloroacetamido-thiazole by its reaction with various types of nucleophiles such as ethyl thioglycolate, 2-mercaptobenzothiazole, 2-mercaptobenzoxazole, ammonium thiocyanate, malononitrile, and salicylaldehyde. The semi-core pseudopods calculations (dspp) were carried out with the double numerical basis sets plus polarization functional (DNP) to predict properties of materials using the hybrid FT/B3LYP method. Antioxidant properties of the synthesized 4-antipyrinyl-thiazole scaffolds were screened by the ABTS radical cation decolorization assay. Among the analogous compounds, $\mathbf{1 0 b}$ and $\mathbf{1 0 c}$ showed excellent antioxidant activity (percentage inhibition of $85.74 \%$ and $83.51 \%$, respectively) very close to the reference inhibitor.

Supplementary Materials: Supplementary materials are available online at http:/ /www.mdpi.com/2076-3417/ 8/11/2128/s1.

Funding: This research received no external funding.

Conflicts of Interest: The authors declare no conflicts of interest.

\section{References}

1. Mahle, F.; Guimarães, T.R.; Meira, A.V.; Corrêa, R.; Cruz, R.B.; Cruz, A.B.; Nunes, R.J.; Cechinel-Filho, V.; Campos-Buzzi, F. Synthesis and biological evaluation of $N$-antipyrine-4-substituted amino-3-chloromaleimide derivatives. Eur. J. Med. Chem. 2011, 45, 4761-4768. [CrossRef] [PubMed]

2. Aly, H.M.; Saleh, N.M.; Elhady, H.A. Design and synthesis of some new thiophene, thienopyrimidine and thienothiadiazine derivatives of antipyrine as potential antimicrobial agents. Eur. J. Med. Chem. 2011, 46, 4566-4572. [CrossRef] [PubMed]

3. Fadda, A.A.; Bondock, S.; Rabie, R.; Etman, H.A. Synthesis and antimicrobial activity of some new heterocycles incorporating antipyrine moiety. Eur. J. Med. Chem. 2008, 43, 2122-2129.

4. Filho, V.C.; Correa, R.; Vaz, Z.; Calixto, J.B.; Nunes, R.J.; Pinheiro, T.R.; Andricopulo, A.D.; Yunes, R.A. Further studies on analgesic activity of cyclic imides. Farmaco 1998, 53, 55-57. [CrossRef] 
5. Ismail, M.M.F.; Ammar, Y.A.; El-Zahaby, H.S.A.; Eisa, S.I.; Barakat, S.E. Synthesis of novel 1-pyrazolylpyridin2-ones as potential anti-inflammatory and analgesic agents. Arch. Pharm. Life Sci. 2007, 340, 476-482. [CrossRef] [PubMed]

6. Metwally, M.A.; Gouda, M.A.; Harmal, A.N.; Khalil, A.M. Synthesis, antitumor, cytotoxic and antioxidant evaluation of some new pyrazolotriazines attached to antipyrine moiety. Eur. J. Med. Chem. 2012, 56, 254-262. [CrossRef] [PubMed]

7. Tao, Z.; Gomha, S.M.; Badrey, M.G.; El-Idreesy, T.T.; Eldebss, T.M.A. Novel 4-heteroaryl-antipyrines: Synthesis, molecular docking, and evaluation as potential anti-breast cancer agents. J. Heterocycl. Chem. 2018, 55, 2408-2416. [CrossRef]

8. Costa, D.; Marques, A.P.; Reis, R.L.; Lima, J.L.F.C.; Fernandes, E. Inhibition of human neutrophil oxidative burst by pyrazolone derivatives. Free Radic. Biol. Med. 2006, 40, 632-640. [CrossRef] [PubMed]

9. Kalyanaraman, B.; Sohnle, P.G. Generation of free radical intermediates from foreign compounds by neutrophil-derived oxidants. J. Clin. Investig. 1985, 75, 1618-1622. [CrossRef] [PubMed]

10. Rouf, A.; Tanyeli, C. Bioactive thiazole and benzothiazole derivatives. Eur. J. Med. Chem. 2015, 97, 911-927. [CrossRef] [PubMed]

11. Carradori, S.; Ortuso, F.; Petzer, A.; Bagetta, D.; De Monte, C.; Secci, D.; De Vita, D.; Guglielmi, P.; Zengin, G.; Aktumsek, A.; et al. Design, synthesis and biochemical evaluation of novel multi-target inhibitors as potential anti-Parkinson agents. Eur. J. Med. Chem. 2018, 143, 1543-1552. [CrossRef] [PubMed]

12. Abdel Hafez, N.A.; Elsayed, M.A.; El-Shahawi, M.M.; Awad, G.E.A.; Ali, K.A. Synthesis and antimicrobial activity of new thiazolidine-based heterocycles as rhodanine analogues. J. Heterocycl. Chem. 2018, 55, 685-691. [CrossRef]

13. Abu-Melha, S. Design, synthesis and DFT/DNP modeling study of new 2-amino-5-arylazothiazole derivatives as potential antibacterial agents. Molecules 2018, 23, 434. [CrossRef] [PubMed]

14. Bekhit, A.A.; Fahmy, H.T.Y.; Rostom, S.A.F.; Bekhit, A. Synthesis and biological evaluation of some thiazolylpyrazole derivatives as dual anti-inflammatory antimicrobial agents. Eur. J. Med. Chem. 2010, 45, 6027-6038. [CrossRef] [PubMed]

15. Amin, K.M.; Kamel, M.M.; Anwar, M.M.; Khedr, M.; Syam, Y.N. Synthesis, biological evaluation and molecular docking of novel series of spiro $[(2 \mathrm{H}, 3 \mathrm{H})$ quinazoline-2,1'-cyclohexan]-4 $(1 \mathrm{H})$ - one derivatives as anti-inflammatory and analgesic agents. Eur. J. Med. Chem. 2010, 45, 2117-2131. [CrossRef] [PubMed]

16. Turan-Zitouni, G.; Kaplancikli, Z.A.; Ozdemir, A. Synthesis and antituberculosis activity of some $N$-pyridyl-N'-thiazolylhydrazine derivatives. Eur. J. Med. Chem. 2010, 45, 2085-2088. [CrossRef] [PubMed]

17. Aridoss, G.; Amirthaganesan, S.; Kim, M.S.; Kim, J.T.; Jeong, Y.T. Synthesis, spectral and biological evaluation of some new thiazolidinones and thiazoles based on t-3-alkyl-r-2,c-6-diarylpiperidin-4-ones. Eur. J. Med. Chem. 2009, 44, 4199-4210. [CrossRef] [PubMed]

18. Kaur, H.; Kumar, S.; Vishwakarma, P.; Sharma, M.; Saxena, K.K.; Kumar, A. Synthesis and antipsychotic and anticonvulsant activity of some new substituted oxa/thiadiazolylazetidinonyl/thiazolidinonylcarbazoles. Eur. J. Med. Chem. 2010, 45, 2777-2783. [CrossRef] [PubMed]

19. Agarwal, A.; Lata, S.; Saxena, K.K.; Srivastava, V.K.; Kumar, A. Synthesis and anticonvulsant activity of some potential thiazolidinonyl 2-oxo/thiobarbituric acids. Eur. J. Med. Chem. 2006, 41, 1223-1229. [CrossRef] [PubMed]

20. Wang, S.; Zhao, Y.; Zhang, G.; Lv, Y.; Zhang, N.; Gong, P. Design, synthesis and biological evaluation of novel 4-thiazolidinones containing indolin-2-one moiety as potential antitumor agent. Eur. J. Med. Chem. 2011, 46, 3509-3518. [CrossRef] [PubMed]

21. Koppireddi, S.; Chilaka, D.R.K.; Avula, S.; Komsani, J.R.; Kotamraju, S.; Yadla, R. Synthesis and anticancer evaluation of 3-aryl-6-phenylimidazo[2,1-b]thiazoles. Bioorg. Med. Chem. Lett. 2014, 24, 5428-5431. [CrossRef] [PubMed]

22. De Santana, T.I.; Barbosa, M.O.; Gomes, P.A.T.M.; da Cruz, A.D.N.; da Silva, T.G.; Leite, A.C.L. Synthesis, anticancer activity and mechanism of action of new thiazole derivatives. Eur. J. Med. Chem. 2018, 144, 874-886. [CrossRef] [PubMed]

23. Lv, P.-C.; Zhou, C.-F.; Chen, J.; Liu, P.-G.; Wang, K.-R.; Mao, W.-J.; Li, H.-Q.; Yang, Y.; Xiong, J.; Zhu, H.-L. Design, synthesis and biological evaluation of thiazolidinone derivatives as potential EGFR and HER-2 kinase inhibitors. Bioorg. Med. Chem. 2010, 18, 314-319. [CrossRef] [PubMed] 
24. Laine, L.; Kivitz, A.J.; Bello, A.E.; Grahn, A.Y.; Schiff, M.H.; Taha, A.S. Double-blind randomized trials of single-tablet ibuprofen/high-dose famotidine vs. ibuprofen alone for reduction of gastric and duodenal ulcers. Am. J. Gastroenterol. 2012, 107, 379-386. [CrossRef] [PubMed]

25. Howard, J.M.; Chremos, A.N.; Collen, M.J.; Mcarthur, K.E.; Cherner, J.A.; Maton, P.N.; Ciarleglio, C.A.; Cornelius, M.J.; Gardner, J.D.; Jensen, R.T. Famotidine, a New, Potent, Long-Acting Histamine $\mathrm{H}_{2}$-Receptor Antagonist: Comparison with Cimetidine and Ranitidine in the Treatment of Zollinger-Ellison Syndrome. Gastroenterology 1985, 88, 1026-1033. [CrossRef]

26. Borelli, C.; Schaller, M.; Niewerth, M.; Nocker, K.; Baasner, B.; Berg, D.; Tiemann, R.; Tietjen, K.; Fugmann, B.; Lang-Fugmann, S.; et al. Modes of action of the new arylguanidine abafungin beyond interference with ergosterol biosynthesis and in vitro activity against medically important fungi. Chemotherapy 2008, 54, 245-259. [CrossRef] [PubMed]

27. Guay, D.R.P. Cefdinir: An advanced-generation, broad-spectrum oral cephalosporin. Clin. Ther. 2002, 24, 473-489. [CrossRef]

28. Yapati, H.; Devineni, S.R.; Chirumamilla, S.; Kalluru, S. Synthesis, characterization and studies on antioxidant and molecular docking of metal complexes of 1-(benzo[d]thiazol-2-yl) thiourea. J. Chem. Sci. 2016, 128, 43-51. [CrossRef]

29. Shubakara, K.; Umesha, K.B.; Srikantamurthy, N.; Chethan, J. Antioxidant and DNA damage inhibition activities of 4-Aryl-N-(4-aryl-thiazol-2-yl)-5,6-dihydro-4H-1,3,4-oxadiazine-2-carboxamides. J. Chem. Sci. 2014, 126, 1913-1921. [CrossRef]

30. Kaupp, G.; Amer, F.A.; Metwally, M.A.; Abdel-Latif, E. Versatile 2-aminothiazoles, building blocks for highly functionalised heterocycles. J. Heterocycl. Chem. 2003, 40, 963-971. [CrossRef]

31. Subbotina, J.O.; Fabian, W.M.F.; Tarasov, E.V.; Volkova, N.N.; Bakulev, V.A. Synthetic and theoretical aspects of new Dimroth rearrangement of 6-aminopyran-2-ones to 6-hydroxypyridin-2-ones via carbamoyl ketenes. Eur. J. Org. Chem. 2005, 2914-2923. [CrossRef]

32. Vicini, P.; Geronikaki, A.; Anastasia, K.; Incerti, M.; Zani, F. Synthesis and antimicrobial activity of novel 2-thiazolylimino-5-arylidene-4-thiazolidinones. Bioorg. Med. Chem. 2006, 14, 3859-3864. [CrossRef] [PubMed]

33. Behbehani, H.; Ibrahim, H.M. 4-Thiazolidinones in heterocyclic synthesis: Synthesis of novel enaminones, azolopyrimidines and 2-arylimino-5-arylidene-4-thiazolidinones. Molecules 2012, 17, 6362-6385. [CrossRef] [PubMed]

34. Delley, B. Hardness conserving semilocal pseudopotentials. Phys. Rev. B 2002, 15, 155125-155129. [CrossRef]

35. Accelrys Software Inc. Materials Studio, Version 6.0; Accelrys Software Inc.: San Diego, CA, USA, 2011.

36. Hehre, W.J.; Radom, L.; Schleyer, P.V.R.; Pople, J.A. Ab Initio Molecular Orbital Theory; John Wiley: New York, NY, USA, 1986.

37. Kessi, A.; Delley, B. Density functional crystal vs. cluster models as applied to zeolites. Int. J. Quantum Chem. 1998, 68, 135-144.

38. Matveev, A.; Staufer, M.; Mayer, M. Density functional study of small molecules and transition-metal carbonyls using revised PBE functionals. Int. J. Quantum Chem. 1999, 75, 863-873. [CrossRef]

39. Hammer, B.; Hansen, L.B.; Nørskov, J.K. Improved adsorption energetics within density-functional theory using revised Perdew-Burke-Ernzerhof functionals. Phys. Rev. B 1999, 59, 7413-7421. [CrossRef]

40. Padmanabhan, J.; Parthasarathi, R.; Subramanian, V.; Chattaraj, P. Electrophilicity-based charge transfer descriptor. J. Phys. Chem. A 2007, 111, 1358-1361. [CrossRef] [PubMed]

41. El-Gammal, O.A.; Bekheit, M.M.; El-Brashy, S.A. Synthesis, characterization and in vitro antimicrobial studies of Co (II), Ni (II) and Cu (II) complexes derived from macrocyclic compartmental ligand. Spectrochim. Acta Part A Mol. Biomol. Spectrosc. 2015, 137, 207-219. [CrossRef] [PubMed]

42. Aliaga, C.; Lissi, E.A. Reaction of 2,2'-azinobis (3-ethylbenzothiazoline-6-sulfonic acid (ABTS) derived radicals with hydroperoxides. Kinetics and mechanism. Int. J. Chem. Kinet. 1998, 30, 565-570. [CrossRef]

43. El-Gazzar, A.B.A.; Youssef, M.M.; Youssef, A.M.S.; Abu-Hashem, A.A.; Badria, F.A. Design and synthesis of azolopyrimidoquinolines, pyrimidoquinazolines as anti-oxidant, anti-inflammatory and analgesic activities. Eur. J. Med. Chem. 2009, 44, 609-624. [CrossRef] [PubMed]

(C) 2018 by the author. Licensee MDPI, Basel, Switzerland. This article is an open access article distributed under the terms and conditions of the Creative Commons Attribution (CC BY) license (http:/ / creativecommons.org/licenses/by/4.0/). 